\title{
The Problems and Countermeasures in the Cultivation of Innovative Entrepreneurship Talents
}

\author{
Zhenbo Bao ${ }^{1, a^{*}}$, Yuan Liu ${ }^{1, b}$, Hongjun Teng ${ }^{1, c}$ \\ Dengchao Jin $^{1, d}$ and Lei Yang ${ }^{1, e}$
}

\author{
${ }^{1}$ Engineering and Technology College, Tianjin Agricultural University, Tianjin, China, 300384 \\ a*zhenbobao@sohu.com, bliuyuan@163.com, chongjun-teng@163.com, \\ jindengchao@163.com, 'yanglei@126.com
}

Keywords: Innovative entrepreneurship talents; Innovation education; Entrepreneurship education; Problems and countermeasures; Cultivation

\begin{abstract}
Higher education is one of the sources of innovation talents training in China, and it is responsible for cultivating innovative talents. However, there are still some problems in the process of innovation and entrepreneurship education, such as the goal of innovation and entrepreneurship education is not clear; the lack of teachers in innovation and entrepreneurship education; innovation and entrepreneurship education curriculum is not enough; the traditional examination is not conducive to the cultivation of innovative entrepreneurship; social support for innovation and entrepreneurship needs to be strengthened, all above which hinders the development of innovative entrepreneurship education. Countries, society, schools, etc., should actively take appropriate measures, such as strengthening the responsibility and consciousness of innovative entrepreneurship education in colleges and universities; strengthening the construction of teaching staff in innovative entrepreneurship education; the construction of innovation and entrepreneurship curriculum system; carrying out the reform of the examination and evaluation system; carrying out innovative funds for venture capital and loan policy support and so on. These measures will contribute to the cultivation of innovative and entrepreneurial talents in colleges and universities.
\end{abstract}

\section{Introduction}

The innovation entrepreneurship education in colleges and universities mainly refers to both innovation education and entrepreneurship education, and focus on entrepreneurship education. Innovation and entrepreneurship education focus on cultivating innovation ability, consciousness and thinking, improves the overall quality of students, to cultivate the innovative spirit and entrepreneurial ability of college students as the goal, and pays attention to personnel training, scientific research and social services. It is an important step to deepen the reform of higher education and improve the quality of personnel training and promote the development of college students. It is the strategic measure to speed up the transformation of economic development mode and the construction of innovative countries. It is an important measure that innovation driven entrepreneurship, entrepreneurship to promote employment, and promote the full employment of college graduates. Therefore, it is not only an effective way to realize the self-development of college students, but also an important measure to alleviate the current employment pressure. It is also an inevitable requirement of China's innovation-driven development strategy [1-2].

\section{The Problems Existing in the Process of Innovation and Entrepreneurship Education}

Colleges and universities actively respond to national policy-oriented, and set up innovative entrepreneurship education courses to improve the innovation and entrepreneurship education environment. The implementation of innovative entrepreneurship training program, organizing innovation and entrepreneurship project competition, entrepreneurial associations, innovation laboratories, and business incubator base platform construction, vigorously promote innovation and entrepreneurship education. However, there are still some problems in the process of innovation and 
entrepreneurship education, which hinders the development of innovative entrepreneurship education. The problems in the process of innovation and entrepreneurship education are shown in Table 1.

Table 1 The problems in the process of innovation and entrepreneurship education[2-4]

\begin{tabular}{|c|c|}
\hline Problems & Specific elaboration \\
\hline $\begin{array}{l}\text { The goal of } \\
\text { innovation and } \\
\text { entrepreneurship } \\
\text { education is not } \\
\text { clear }\end{array}$ & $\begin{array}{l}\text { Some colleges and universities on the lack of awareness of innovation and } \\
\text { entrepreneurship education goals, innovative entrepreneurship education in a } \\
\text { vacant state or in the form of one-sided that innovation and entrepreneurship } \\
\text { education is equivalent to participate in national or local events; innovative } \\
\text { entrepreneurship education simply push to learn job sector, distort that } \\
\text { innovation and entrepreneurship education is a small number of students } \\
\text { interested in entrepreneurship guidance; lack of innovative entrepreneurship } \\
\text { education and professional education integration mechanism. }\end{array}$ \\
\hline $\begin{array}{l}\text { The lack of } \\
\text { teachers in } \\
\text { innovation and } \\
\text { entrepreneurship } \\
\text { education }\end{array}$ & $\begin{array}{l}\text { The innovation and entrepreneurship education requires that teachers not only } \\
\text { have rich theoretical knowledge and entrepreneurial experience, but also need } \\
\text { inter-disciplinary background including financial management, psychology and } \\
\text { management. However, the teachers of the university themselves do not have the } \\
\text { entrepreneurial experience; in addition, because the university teachers } \\
\text { themselves bear heavy research and teaching tasks, there are not enough energy } \\
\text { to innovate the entrepreneurial course system and deep research. Therefore, most } \\
\text { college teachers are difficult to shoulder the responsibility of innovation and } \\
\text { entrepreneurship education. }\end{array}$ \\
\hline $\begin{array}{l}\text { Innovation and } \\
\text { entrepreneurship } \\
\text { education } \\
\text { curriculum is not } \\
\text { enough }\end{array}$ & $\begin{array}{l}\text { Some colleges and universities innovation and entrepreneurship curriculum } \\
\text { system is not systematic, the innovation and entrepreneurship education not into } \\
\text { the discipline construction planning, the teaching effect of innovative } \\
\text { entrepreneurship education curriculum is poor. Because that lack of knowledge } \\
\text { of the various disciplines systematic and comprehensive construction, students } \\
\text { only know a single professional knowledge and simple application, not } \\
\text { conducive to the cultivation of original thinking. Innovative entrepreneurship } \\
\text { education and college students' career planning education is out of touch, and } \\
\text { there are few practical teaching links. }\end{array}$ \\
\hline $\begin{array}{l}\text { The traditional } \\
\text { examination is } \\
\text { not conducive to } \\
\text { the cultivation of } \\
\text { innovative } \\
\text { entrepreneurship }\end{array}$ & $\begin{array}{l}\text { The course examination is one of the important means to evaluate and enhance } \\
\text { students' innovative thinking and innovation ability. The contents of the course } \\
\text { examination are limited to the study of teaching materials and classroom notes, } \\
\text { which restricts the cultivation of students' independent thinking ability and } \\
\text { flexible use of knowledge ability. Emphasizing on the examination process and } \\
\text { test scores, ignoring the examination information analysis, result in students that } \\
\text { only to cope with examinations and learning, ignore the development of their } \\
\text { own innovative consciousness and innovation ability. }\end{array}$ \\
\hline $\begin{array}{l}\text { Social support for } \\
\text { innovation and } \\
\text { entrepreneurship } \\
\text { needs to be } \\
\text { strengthened }\end{array}$ & $\begin{array}{l}\text { Business difficulties are lack of funds, although the state and all levels of } \\
\text { government have increased the enthusiasm of college students to support } \\
\text { innovation, but the tax relief is limited. Limited to less practical experience, less } \\
\text { innovative products, entrepreneurial teams, professionals and other reasons, it is } \\
\text { difficult to get venture capital investment. The social statuses of small and } \\
\text { medium-sized enterprises are not high, the burden of enterprises is heavy, and } \\
\text { the living environment needs to be improved. The parents are more educated for } \\
\text { their children to choose high-paying, high-status, high-welfare civil servants. }\end{array}$ \\
\hline
\end{tabular}

\section{The Countermeasures in the Cultivation of Innovative Entrepreneurship Talents}


Countries, society, schools, etc., are actively adopting appropriate strategies to innovate and improve the environment of college students' innovation and entrepreneurship. The countermeasures in the cultivation of innovative entrepreneurship talents are shown in Table 2.

Table 2 The countermeasures in the cultivation of innovative entrepreneurship talents [3-6]

\begin{tabular}{|c|c|}
\hline Countermeasures & Specific elaboration \\
\hline $\begin{array}{l}\text { Strengthening the } \\
\text { responsibility and } \\
\text { consciousness of } \\
\text { innovative } \\
\text { entrepreneurship } \\
\text { education in } \\
\text { colleges and } \\
\text { universities }\end{array}$ & $\begin{array}{l}\text { Colleges and universities should strengthen the responsibility of innovation and } \\
\text { entrepreneurship education, set up innovative business management specialized } \\
\text { agencies to strengthen the curriculum system construction, teaching methods, } \\
\text { teacher team building, practical teaching mechanism construction, innovation } \\
\text { practice activities, employment training and other work. Establishing and } \\
\text { improving the innovative entrepreneurial talent training education system, from } \\
\text { the theoretical teaching, academic research, research activities, entrepreneurial } \\
\text { training and entrepreneurial practice, the maximum use of school resources for } \\
\text { innovation and entrepreneurship education. }\end{array}$ \\
\hline $\begin{array}{l}\text { Strengthening the } \\
\text { construction of } \\
\text { teaching staff in } \\
\text { innovative } \\
\text { entrepreneurship } \\
\text { education }\end{array}$ & $\begin{array}{l}\text { Colleges and universities can first integrate the school teachers, according to } \\
\text { innovative entrepreneurship training program to carry out innovative } \\
\text { entrepreneurship teaching, educates teachers with financial management, } \\
\text { psychology, management and other interdisciplinary background, as well as the } \\
\text { teachers with a strong theoretical and practical level of innovative } \\
\text { entrepreneurship education faculty. Second, the introduction of extracurricular } \\
\text { strength, the school can strengthen cooperation with research institutes, industry } \\
\text { enterprises, etc., to hire industry experts, successful entrepreneurs, as part-time } \\
\text { teachers, with successful experience to guide students, can inspire college } \\
\text { students the idea of entrepreneurship, and broaden the vision of college students' } \\
\text { innovation and entrepreneurship. }\end{array}$ \\
\hline $\begin{array}{l}\text { The construction } \\
\text { of innovation and } \\
\text { entrepreneurship } \\
\text { curriculum } \\
\text { system. }\end{array}$ & $\begin{array}{l}\text { The basic course of innovation and entrepreneurship is included in the scope of } \\
\text { general education curriculum, and the course content is integrated with the } \\
\text { professional course. The innovation and practice course should be combined } \\
\text { with entrepreneurial training, innovation and entrepreneurship competition and } \\
\text { innovation practice of science and technology park, for students to provide a } \\
\text { variety of practice opportunities and channels. The teaching content system } \\
\text { includes compulsory courses, elective courses and practical lessons. In the first } \\
\text { year of college to set up "impulse thinking development", "innovation ability } \\
\text { training" and other compulsory courses. In the second year of college to set up } \\
\text { "college students innovation and entrepreneurship", "college students } \\
\text { entrepreneurship guide" and other compulsory courses. In the third grade of the } \\
\text { university to set up professional elective courses such as "venture financing", } \\
\text { "business plan writing" and "business model development". In the fourth grade } \\
\text { of the university, the teaching content of the practical course will be embodied } \\
\text { into various practical projects. }\end{array}$ \\
\hline $\begin{array}{l}\text { Carrying out the } \\
\text { reform of the } \\
\text { examination and } \\
\text { evaluation system. }\end{array}$ & $\begin{array}{l}\text { By adjusting the form of examination, rich examination content, etc. to carry out } \\
\text { the reform of evaluation system. In the evaluation assessment, the students who } \\
\text { are actively speaking, actively performing, generating new ideas and new ideas } \\
\text { in the course of the course, and have excellent achievements of the practice of } \\
\text { innovation and entrepreneurship, are encouraged by extra points of the } \\
\text { innovation and entrepreneurship. Through the reform of assessment evaluation, } \\
\text { to cultivate students independent thinking, to explore the spirit of innovation, } \\
\text { and to improve student learning initiative. }\end{array}$ \\
\hline $\begin{array}{l}\text { Setting up } \\
\text { innovative funds } \\
\text { for venture capital } \\
\text { and loan policy } \\
\text { support. }\end{array}$ & $\begin{array}{l}\text { State adjusts the industry policy to support small and medium enterprises, } \\
\text { establishes innovative funds and loans for entrepreneurship, the form of funds } \\
\text { can have the following forms: first, the high school venture capital model: the } \\
\text { school took out part of the special funds as a venture fund; second, the } \\
\text { entrepreneurial fund model: students jointly funded the establishment of college } \\
\text { students entrepreneurship fund to help students or graduates to participate in } \\
\text { innovation project research and development; third, the enterprise venture } \\
\text { capital model: funded by the enterprises to establish innovative business funds; } \\
\text { fourth, the entrepreneurial loan model: the state to give loans to support policies, } \\
\text { colleges and universities actively take measures to help innovative } \\
\text { entrepreneurship for national loans. }\end{array}$ \\
\hline
\end{tabular}




\section{Summary}

In the ordinary colleges and universities to carry out innovation and entrepreneurship education, is a strategic initiatives to serve the country accelerating the transformation of economic development, build an innovative country and human resources. It is an important way to speed up the reform of higher education, to improve the quality of personnel training and promote the development of college students. It is an important measure that the implementation of innovation to promote entrepreneurship, entrepreneurship to promote employment, and promote the full employment of college graduates. Therefore, it is great practical significance for taking corresponding improvement measures to improve the innovation and entrepreneurial talents for the problems of innovation and entrepreneurship [7-8].

\section{Acknowledgements}

This work was sponsored by Tianjin Agricultural University Teachers Education Reform and Innovation to Guide the Development of the Project No. 20170904 and Tianjin Agricultural University Education and Teaching Reform Project No. 2016-B-17.

\section{References}

[1] Y.J.Yang, J.Z.Zhao, X.G.Li: China Economist, (2015) No.2, pp. 226-228.

[2] K.M.Yuan: JOURNAL OF EDUCATIONAL INSTITUTE OF JILIN PROVINCE, Vol. 31(2015) No.1, pp. 37-38.

[3] S.J.Peng, Y.Zhou, X.Li: Education Teaching Forum, (2015) No.2, pp.112-114.

[4] R.M.Cao, Q.W.Ran: Journal of Chinese Youth Social Science, Vol. 35 (2015) No.182, pp.104-108.

[5] K.L.Liang: JOURNAL OF HUANGHE S \& T UNIVERSITY, Vol. 17 (2015) No.6, pp. 116-118.

[6] Z.Y.Ju, X.H.Chen, X.H.Jia, C.Z.Wu: CHUANGXIN YU CHUANGYE JIAOYU, Vol. 6 (2015)No.1, pp. 75-76.

[7] Y.Zhang: Guangzhou Chemical Industry, Vol. 44 (2016) No.4, pp.184-185.

[8] Y.Yang, B.Wang, D.L.Yang: Journal of Changchun University of Science and Technology (Social Sciences Edition), Vol. 29 (2016) No.1, pp.143-146. 